Virtual Mentor. February 2004, Volume 6, Number 2.

doi: 10.1001/virtualmentor.2004.6.2.medu1-0402

Medical Education

\title{
On Distinguishing Justifiable from Unjustifiable Paternalism
}

\section{Limiting the right of patients to make their own medical decisions can be justified only when a patient lacks the competence to do so or pose a threat to others.}

\author{
Loretta Kopelman, PhD
}

Paternalism is the interference with people's liberties or autonomy "for their own good" or to "prevent their harm" irrespective of the preferences of the person whose liberty is being curtailed [1]. A powerful way to understand the issues and controversies about paternalism in medicine is to consider the case of Dax Cowart, who was severely injured after a gas explosion caused second and third degree burns over 67 percent of his body [2]. A 1974 film, shot 10 months after the accident, shows Cowart undergoing painful but life-saving treatments. The film mostly consists of Cowart's interviews with Robert White, a psychiatrist at the University of Texas at Galveston. Burn unit doctors told White that Cowart was irrational and depressed and needed to be declared incompetent so his mother could be appointed his legal guardian and authorize surgery on his hands.

Unlike doctors in the burn unit, the surgeons refused to operate unless Cowart gave informed consent or was declared legally incompetent and a court-appointed surrogate authorized surgery. Dr. White and another psychiatrist found Cowart to have the capacity to make his own medical decisions and refused to participate in the process to have him declared legally incompetent. Yet Cowart's doctors were still unwilling to honor Cowart's refusals of treatments. Eventually Cowart agreed to the surgery because, he said, he believed that it was the fastest route out of the hospital, where he could reestablish control over his life [3].

The difficulty with paternalism for legally competent persons is that, first, someone's sincere belief about what is good for another person may be wrong. With the best intentions people may be mistaken about what harms or benefits others [4]. Doctors were wrong in assuming what values were most important to Cowart and in predicting that he would regain some vision and use of his hands, be able to dress himself, and attend to his personal needs. Second, limiting the liberty of competent persons offers insufficient respect for their autonomous actions or their ability to make decisions for themselves. People find it intrinsically valuable to plan their own lives and live as they wish [5]. Third, there is utility or instrumental value in letting people live as they wish because competent people generally are the best judges of what is best for them and because we learn from each other's successes and failures [6]. In deciding for ourselves, moreover, we develop our potential as autonomous persons, gain respect from others, and do not feel thwarted. Paternalism is generally considered an unwarranted interference with the liberties of people who can act autonomously because it undercuts what they want for themselves and their liberty to live out their lives as they wish as long as they do not interfere with others. Current laws and policies generally do not permit medical paternalism for legally competent persons.

Sometimes we are not sure whether persons are competent who, in our view, are about to harm themselves. In such cases, it seems appropriate, perhaps even a moral duty, to interfere to determine if the person is competent. For example, a seemingly competent person may want to fly from a 15th story window, eat poisonous mushrooms, or walk into a minefield. Weak paternalism permits interference with the liberty of others to determine whether they are 
competent or capable of making a rational choice [7-9]. Most people would argue that it is justifiable to interfere with persons about to harm themselves to determine if they have the capacity to look after their interests, understand the consequences of what they are doing, or act voluntarily. Weak paternalism honors the autonomous decisions of competent persons while also protecting people who may be acting nonautonomously or on insufficient information. Weak paternalism is especially important in medicine since it extends more protection to people who are impaired by such things as illness, ignorance, drugs, or fear.

When Cowart was first taken to the hospital he demanded that the clinicians let him die. Since Cowart was disoriented and hallucinating, his doctors could justify treating Cowart over his objections, using this widely defended principle of weak paternalism. As the months went by and he became articulate, clear in his reasoning, and unwavering in his refusals of burdensome treatments, it became increasingly difficult for physicians to use the defense of weak paternalism.

Cowart is now a lawyer defending patients' rights. He insists that, while he is happy to be alive, he was not treated with respect, and his competent refusal should have been honored. He was more accurate in predicting the severe limitations with which he lives and claims that the result was not worth his suffering. Honoring a patient's competent refusal of a burdensome treatment does not constitute participation in a suicide, as some doctors feared. One would hope that Cowart's doctors would have recommended or even implored him to consider life-saving treatments or meet persons with disabilities who were living full and happy lives. Still, they crossed a legal and moral line in treating this highly competent man against his will without even a court hearing.

First-year medical students at the Brody School of Medicine watch the film about Cowart, Please Let Me Die, in our medical humanities course [2]. It introduces them to issues of competency, informed consent, and paternalism. Most, if not all, students agree with the psychiatrists but struggle with the difficult choice faced by his doctors. Compassion seems to lead them in one direction and respect for liberty in another. There is no conflict between the need to protect sick people and to honor their self-determination when they authorize recommended treatments or hospitalizations. The problems arise when we cannot simultaneously do what we think is best for people and also respect their refusal of treatment or hospitalization, and solutions often depend on competency determinations.

\section{Justifiable Paternalism}

Paternalism is justifiable if someone lacks the capacity to look after his or her interests. Some form of protection is justified or even obligatory when people cannot make decisions for themselves, suffer incapacitating illnesses, show involuntary self-destructive behavior, or make choices so inappropriate to their own established life goals that we doubt their autonomy. Interference seems justified in the presence of people's nonautonomous, self-destructive behavior or when they resort to acts that are irrational, unreasonable, and uncharacteristic. Thus, paternalism (some prefer the less sexist word "parentalism") is sometimes a duty in medicine, and clinicians have to decide when they should act like good parents and help people who cannot look out for themselves.

For example, temporary involuntary commitment of a patient may ultimately enlarge that person's liberty [8]. Civil commitment laws for persons considered dangerous to themselves are paternalistic in the sense that they interfere with the liberty or autonomy of such persons for their own good or to prevent harm. The justification for these laws is that people sometimes lack the capacity to act in their own interest. When people are very ill, they are "not themselves" and are not choosing autonomously. As a society, we can even adopt paternalistic laws for competent adults, such as requiring motorists to wear seatbelts, motorcyclists to wear helmets, prohibiting swimming in dangerous areas, and requiring parents to protect their children. Doctors, however, are private citizens and cannot restrain the liberties of others simply because they do not like competent patients' decisions.

Limiting the liberty of others can be justified if they lack capacity to make the relevant decision (paternalism), if they pose harm to others (the harm principle), or if their behavior is so bizarre that we should intervene to allow time to determine if their actions are autonomous and informed (weak paternalism). Interference with the liberty of adults requires a heavy burden of proof to show they are incapacitated, incompetent, or a threat to themselves or others. It requires proving that the probability and magnitude of the possible harm merits the interference and that the means used are effective and the least restrictive means available [10-11]. 


\section{References}

1. Dworkin G. Paternalism. In: Audi R, ed. Cambridge Dictionary of Philosophy. New York: Cambridge University Press; 1995: 564.

Google Scholar

2. Please Let Me Die [film]. Galveston: University of Texas, Department of Psychiatry; 1974.

3. Dax's Case [film]. New York: Concerns for Dying; 1985.

4. Kopelman L. Moral problems in psychiatry: the role of value judgments in psychiatric practice. In: Veatch R, ed. Medical Ethics. 2nd ed. Boston, MA: Jones and Bartlett Publishing Company; 1997: 275-320.

5. Dworkin, G. Autonomy and behavior control. Hastings Cent Rep. 1976;6:23-28. View Article PubMed Google Scholar

6. Mill JS. On Liberty. Himmelfarb G, ed. Harmondsworth: Penguin; 1974. Google Scholar

7. Feinberg J. Legal paternalism. Can J Philosoph. 1971:105-124. Google Scholar

8. Feinberg J. Freedom and behavior control. In: Reich WT, ed, Encyclopedia of Bioethics v 1. New York: The Free Press; 1978:93-101. PubMed Google Scholar

9. VanDeVeer D. Paternalistic Intervention: The Moral Bounds of Benevolence. Princeton: Princeton University Press; 1986.

Google Scholar

10. Kopelman L. On the evaluative nature of competency and capacity Judgments. Intl J Law Psychiatr. Fall, 1990;13:309-329. View Article PubMed Google Scholar

11. Beauchamp TL. Paternalism. In: Post SG, ed. Encyclopedia of Bioethics. 3rd ed. MacMillan Library Reference; November 2003:1983-1989.

Google Scholar

Loretta M. Kopelman, PhD, is professor and chair of the Department of Medical Humanities in the Brody School of Medicine at East Carolina University. She founded the Department of Medical Humanities in 1978 and was founding president of the American Society for Bioethics and Humanities.

The viewpoints expressed on this site are those of the authors and do not necessarily reflect the views and policies of the AMA.

(C) 2004 American Medical Association. All Rights Reserved. 